\title{
Analisis Kinerja Keuangan Dengan Menggunakan Rasio Likuiditas terhadap Kinerja Organisasi
}

\author{
Dede Slamet ${ }^{1}$, Ramdany ${ }^{2}$, \\ ${ }^{1}$ STIE Muhammadiyah Jakarta, slamet@ stiemj.ac.id \\ ${ }^{2}$ STIE Muhammadiyah Jakarta, ramdany2012@gmail.com
}

\begin{abstract}
ABSTRAK
Tujuan Penelitian untuk Analisis Kinerja Keuangan Dengan Menggunakan Rasio Likuiditas Terhadap Kinerja Organisasi Study Kasus Pada PT JIEP Pulogadung. Metode yang digunakan metode analisa rasio keuangan yang ada yakni laporan keuangan tahun 2010, tahun 2011, Tahun 2012, tahun 2013, tahun 2014, dan tahun 2015. Dengan dilakukannya penilaian melalui alat analisa rasio diharapakan dapat mengetahui kemajuan-kemajuan yang telah dihasilkan oleh manajemen dalam menjalankan perusahaannya.Hasil penelitian menunjukkan bahwa Cash Ratio secara parsial berpengaruh positif dan signifikan terhadap Kinerja Organisasi. Current Ratio secara parsial tidak berpengaruh signifikan terhadap profit Study. Anggaran pendapatan dan anggaran biaya secara simultan berpengaruh signifikan terhadap profit Study.
\end{abstract}

Kata Kunci : Kinerja Keuangan dan Kinerja Organisasi.

\section{ABSTRACT}

Research Objectives for Analysis of Financial Performance Using Liquidity Ratios on Organizational Performance Case Study at PT JIEP Pulogadung. The method used is the existing financial ratio analysis methods, namely the 2010, 2011, 2012, 2013, 2014, 2014, and 2015 financial statements. By evaluating through the ratio analysis tool, it is expected to be able to know the progress made by management in running the company. The results of the research show that Cash Ratio partially has a positive and significant effect on Organizational Performance. Current Ratio partially has no significant effect on profit studies. Revenue budget and cost budget simultaneously have a significant effect on profit study.

Keywords : Financial Performance and Organizational Performance. 



\section{PENDAHULUAN}

Laporan keuangan merupakan alat yang sangat penting untuk memperoleh informasi mengenai posisi keuangan perusahaan dan hasil usaha yang telah dicapai oleh perusahaan. Karena laoran keuangan merupakan dasar bagi upaya analitis atas suatu perusahaan, maka petama-tama kita harus mengerti sifat, cakupan, dan keterbatasannya sebelum kita menggunakan data serta observasi yang dihasilkan dari laporan keuanganuntuk pertimbangan analitis kita. Salah satu bentuk informasi yang dapat digunakan untuk mengetahui kondisi dan perkembangan suatu perusahaan adalah laporan keuangan yang dilaporkan setiap akhir periode sebagai laporan pertanggungjawaban atas pengelolaan suatu perusahaan (Erich A. Helfert,1996:24). Analisis laporan keuangan dalam banyak hal mampu menyediakan indikator penting yang berhubungan dengan keadaan keuangan perusahaan, sehingga dapat dipakai sebagai alat pertimbangan dalam mengambil keputusan keuangan dan sekaligus menggambarkan kinerja pada perusahaan.

Penilaian kinerja keuangan dilakukan melalui analisis laporan keuangan, untuk itu diperlukan pengukuran kinerja perusahaan agar perusahaan dapat mengetahui pemanfaatan sumber daya yang dimiliki serta untuk mengetahui apakah perusahaan berkembang, bertahan, atau mengalami kegagalan. Prospek bisa di lihat dari tingkat keuntungan dan rasio bisa dilihat dari kemunkinan perusahaan mengalamai kesulitan keuangan atau mengalami kebangkrutan. (Mamduh M. Hanafi, 2005:21)

Analisis laporan keuangan, yang menghubungkan antara unsur-unsur neraca dan perhitungan rugi/laba satu dengan yang lainnya, dapat memberikan gambaran tentang sejarah perusahaan dan penilaian posisinya pada saat ini. Analisis rasio juga memunkinkan manajer keuangan memperkirakan reaksi para kreditur dan investor dalam memberikan pandangan ke dalam tentang bagaimana kira-kira dana dapat diperoleh (Sawir, 2005: 6).

Laporan keuangan yang terdiri atas neraca, laporan laba rugi, laporan perubahan ekuitas, catatan atas laporan keuangan, laporan perubahan modal serta laporan arus kas. Dengan menggunakan rasio keuangan untuk menganalisa pos-pos neraca akan dapat diketahui atau diperoleh gambaran posisi keuangan perusahaan, sedangkan analisa terhadap laporan laba rugi akan memberikan gambaran tentang hasil dan perkembangan perusahaan.

Laporan keuangan pada umumnya digunakan secara luas baik oleh pihak internal maupun oleh pihak eksternal perusahaan. Pihak internal adalah pihak yang membutuhkan informasi dari hasil analisis laporan keuangan untuk membantu mereka dalam mengelola, merencanakan dan mengendalikan kegiatan perusahaan. Pihak internal perusahaan terdiri dari manajemen perusahaan, para pembuat keputusan di perusahaan dan staf perusahaan.

Keputusan yang diambil oleh pihak internal akan secara langsung mempengaruhi kegiatan perusahaan. Pihak eksternal adalah pihak yang membutuhkan informasi dari hasil analisis laporan keuangan suatu perusahaan untuk pengambilan keputusan yang menyangkut hubungan mereka dengan perusahaan tersebut. Pihak eksternal terdiri dari para investor, kreditor, pemerintah dan masyarakat umum. Oleh karena itu perusahaan akan selalu mempublikasikan laporan keuangan agar pihak eksternal dapat mengetahui bagaimana kinerja perusahaan dan prospek perusahaan tersebut ke depannya

PSAK No.1 tentang penyajian lapora keuangan (revisi 2009) menyatakan laporan keuangan adalah suatu penyajian terstruktur dari posisi keuangan dan kinerja keuangan suatu entitas. Jadi laporan keuangan merupakan salah satu informasi yang sangat penting dalam menilai perkembangan perusahaan. Laporan keuangan dapat digunakan untuk menilai prestasi yang dicapai perusahaan pada saat lampau, sekarang dan rencana pada waktu yang akan datang. Dalam pengertian yang sangat sederhana menurut kasmir (2008:7) laporan keuangan adalah laporan yang menunjukan kondisi keuangan perusahaan pada saat ini atau dalam periode. Untuk mengetahui apakah laporan keuangan suatu perusahaan dalam keadaan baik dapat dilakukan berbagai analisis rasio, antara lain rasio likuiditas, solvabilitas, profabilitas, dan aktivitas, yang dijadikan dasar untuk menghitung analisis rasio adalah neraca dan laporan laba rugi. 


\section{JURNAL AKUNTANSI, Vol. 7, No. 2, November (2018)}

Secara umum, rasio likuiditas, solvabilitas, profabilitas, dan aktivitas merupakan salah satu indikator penting dari laporan keuangan. Sehingga apabila rasio likuiditas, solvabilitas, profabilitas, dan aktivitas suatu perusahaan menunjukkan hasil yang baik, maka kinerja keuangan perusahaan tersebut menunjukkan hasil yang baik pula.

Berdasarkan uraian latar belakang tujuan penelitian ini adalah untuk menguji analisis kinerja keuangan dengan menggunakan rasio likuiditas terhadap kinerja organisasi pada PT JIEP Pulogadung.

\section{KAJIAN LITERATUR}

\section{Kinerja keuangan}

Dalam mengukur kinerja keuangan perusahaan dengan tujuan untuk mengetahui kemampuan perusahaan dalam memenuhi kewajiban atau hutang dalam jangka waktu pendek, perusahaan dapat mengukur dengan menggunakan rasio likuiditas.

\section{Analisis Rasio Keuangan}

\section{Rasio likuiditas:}

a. Rasio Lancar (Current ratio)

Rasio Lancar $=\frac{\text { Aset Lancar }}{\text { Utang Lancar }}$

b. Cash Ratio ( Ratio Tunai)

Cash Ratio $=\frac{\text { Kas }+ \text { Bank }}{\text { Hutang Lancar }}$

\section{Kinerja Organisasi}

Dengan berpedoman pada KPKU, maka tiap BUMN dapat menilai semua elemen di perusahaan tersebut yang berpengaruh pada pengelolaan perusahaan, peningkatan proses, dan peningkatan hasil. Dengan adanya KPKU sebagai pedoman dan alat ukur, maka BUMN diharapkan dapat merancang keunggulan kinerja organisasi, mendiagnosa sistem manajemen kinerja secara keseluruhan, mengidentifikasi kelemahan dan kekuatan organisasi, serta menilai upaya perbaikan kinerja. Ada sebelas tata nilai dan konsep yang dimiliki perusahaan-perusahaan berkinerja tinggi yang perlu diteladani dan dicontoh. Sedangkan kategorinya tetap tujuh poin, dengan enam poin berfokus pada proses dan satu poin membahas tentang hasil. Tata nilai dan konsep tersebut meliputi kepemimpinan yang memiliki visi, keunggulan yang digerakkan pelanggan, pembelajaran organisasi dan individu, menghargai tenaga kerja dan mitra, kelincahan (agility), fokus ke masa depan, manajemen inovasi, manajemen berdasarkan fakta, tanggung jawab kemasyarakatan, fokus pada hasil dan penciptaan nilai, serta perspektif kesisteman. Sementara tujuh kategori yang berisikan beragam pertanyaan tentang kondisi riil perusahaan adalah kepemimpinan; perencanaan strategis; fokus pelanggan; pengukuran, analisis, dan manajemen pengetahuan; fokus tenaga kerja; fokus operasi; dan hasil-hasil.

Perseroan bekerja sama dan memberikan bantuan program kemitraan dengan pihakpihak yang dapat dipercaya, perseroan berusaha cermat dalam memilih mitra yang berhak menerima program kemitraan dan bantuan sosial agar tidak berdampak buruk terhadap reputasi perseroan, struktur pengelolaan program dan bina lingkungan di PT. JIEP dilaksanajan berdasarkan surat keputusan direksi No. 87 tahun 2014 tanggal 23 Desember 2014, dimana PKBL berada di bawah Corporate secretariate dan langsung di bawah pembinaan Direktur, dan berdasarkan Peraturan Menteri BUMN No. PER-09/MBU/07/2015 dan keputusan RUPS penetapan RPA PKBL diputuskan bahwa alokasi dana Bina Lingkungan sudah tidak dianggarkan lagi. Perubahan tersebut terkait implementasi Program Kemitraan dan Bina Lingkungan (PKBL) yaitu:

1. Sumber dana PKBL berasal dari laba setelah pajak tahun buku sebelumnya 
2. Bantuan pendidikan, pelatihan, pemagangan, pemasaran, promosi dan bentuk lain yang terkait dengan upaya peningkatan kapasitas Mitra Binaan Program Kemitraan diambil dari alokasi dana Program BL maksimal 20\% yang diperhitungkan dari dana Program Kemitraan

3. Beban operasional PKBL menjadi beban BUMN pembina.

\section{Pengukuran Kinerja Organisasi}

Tabel 1. GCG (Peraturan Menteri BUMN Nomor. Per-01/MBU/2011)

\begin{tabular}{|l|l|c|c|c|}
\hline No & \multicolumn{1}{|c|}{ Aspek Governance } & Bobot & $\begin{array}{c}\text { Capaian Bobot } \\
\text { Aktual }\end{array}$ & $(\%)$ \\
\hline 1. & $\begin{array}{l}\text { Komitmen terhadap tata kelola } \\
\text { secara berkelanjutan }\end{array}$ & 7 & & \\
\hline 2. & $\begin{array}{l}\text { Pemegang saham dan RUPS/pemilik } \\
\text { modal }\end{array}$ & 9 & & \\
\hline 3. & Dewan Komisaris/Dewan Pengawas & 35 & & \\
\hline 4. & Direksi informasi dan & 35 & & \\
\hline 5. & $\begin{array}{l}\text { Pengungkapan } \\
\text { transparasi }\end{array}$ & 5 & & \\
\hline 6. & Aspek Lainnya & 100,00 & & \\
\hline & Total & & \\
\hline
\end{tabular}

\section{Pengembangan Hipotesis}

Menurut Wati (2017) "Hipotesis merupakan jawaban sementara terhadap rumusan masalah penelitian, dimana rumusan masalah penelitian telah dinyatakan dalam bentuk kalimat pertanyaan."

Berdasarkan penelitian sementara yang penulis lakukan, maka didapatkan hipotesis dalam penelitian ini adalah penilaian kinerja keuangan dan kinerja perusahaan berpengaruh besar terhadap laporan keuangan perusahaan.

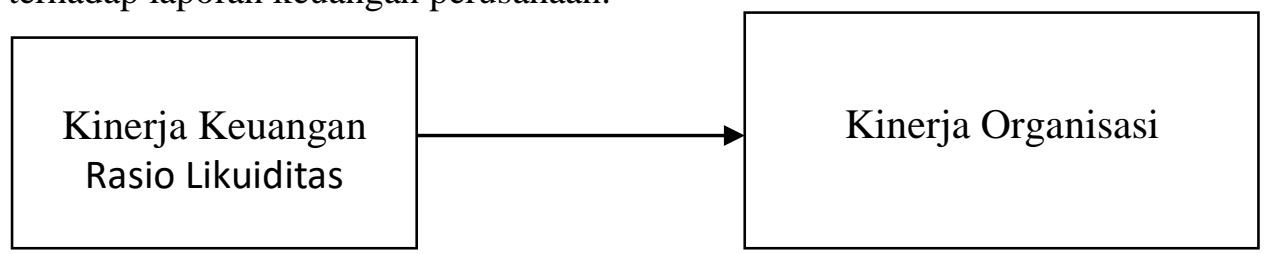

\section{Gambar 1. Kerangka Pikir}

\section{METODE PENELITIAN}

Penelitian ini dilakukan pada perusahaan PT JIEP pulogadung. Populasi yang digunakan dalam penelitian ini adalah perusahaaan PT JIE. Sampel yang digunakan oleh penulis dalam penelitian ini adalah laporan keuangan PT JIEP Pulogadung pada tahun 2010, tahun 2011, Tahun 2012, tahun 2013, tahun 2014, dan tahun 2015yang terdapat dalam laporan tahunan (Annual report) perusahaan.

\section{ANALISIS DAN PEMBAHASAN}

Berikut merupakan uraian tentang data dan fakta yang relevan berhasil dikumpulkan terhadap PT JIEP atau objek penelitian yang relevan dengan penelitian yang dilakukan. Disajikan dalam tabel 4.1 Metode dan Rumus Rasio Keuangan dan tabel 4.2 Neraca. 
Tabel 4.2. Kinerja Perusahaan

\begin{tabular}{|r|r|}
\hline Tahun & $\begin{array}{c}\text { Kinerja } \\
\text { Perusahaan }\end{array}$ \\
\hline $\mathbf{2 0 1 5}$ & 68.45 \\
\hline $\mathbf{2 0 1 4}$ & 84.00 \\
\hline $\mathbf{2 0 1 3}$ & 78.68 \\
\hline $\mathbf{2 0 1 2}$ & 77.17 \\
\hline $\mathbf{2 0 1 1}$ & 77.17 \\
\hline $\mathbf{2 0 1 0}$ & 77.17 \\
\hline
\end{tabular}

PT JIEP adalah Badan Usaha Milik Negara di bidang pengelolaan kawasan terpadu. Dalam melakukan aktivitas usahanya yakni dari tahun 2010 s/d tahun 2015 mengalami peningkatan. Oleh karena itulah perlu adanya analisis rasio keuangan, sehingga dalam penelitian ini lebih ditekankan pada periode tahun pengamatan tahun $2010 \mathrm{~s} / \mathrm{d}$ tahun 2015.

\section{Uji Asumsi Klasik}

Hasil uji asumsi klasik menunjukan bahwa uji normalitas terpenuhi, dengan menggunakan uji statistik non-parametrik Kolmogorov-Smirnov (K-S) yang mana kriteria suatu data residual berdistribusi normal yaitu nilai Asymp. Sig. (2-tailed) $>0,05$ dan hasil menunjukan bahwa data dalam penelitian ini berdistribusi normal karena nilai nya Kolmogorov-Smirnov $>0.05$ yaitu 0.133. kemudian untuk uji multikolinieritas hasil nya menunjukan bahwa antara variabel harga, dan kualitas produk tidak berkorelasi atau multikolinieritas tidak terjadi dalam model penelitian karena diperoleh nilai VIF lebih kecil dari 10 yaitu 3.083 untuk cash rasio dan current rasio. Hasil uji heteroskedastisitas menunjukan bahwa tidak terjadi heteroskedastisitas karena terlihat pada titik-titik yang menyebar secara acak diatas dan dibawah angka nol (0) dan tidak membentuk suatu pola tertentu, maka dapat dikatakan bahwa regresi tidak mengalami ganguan heteroskedastisitas sehingga model regresi layak dipakai untuk memprediksi kinerja kerja berdasarkan masukan variabel bebas

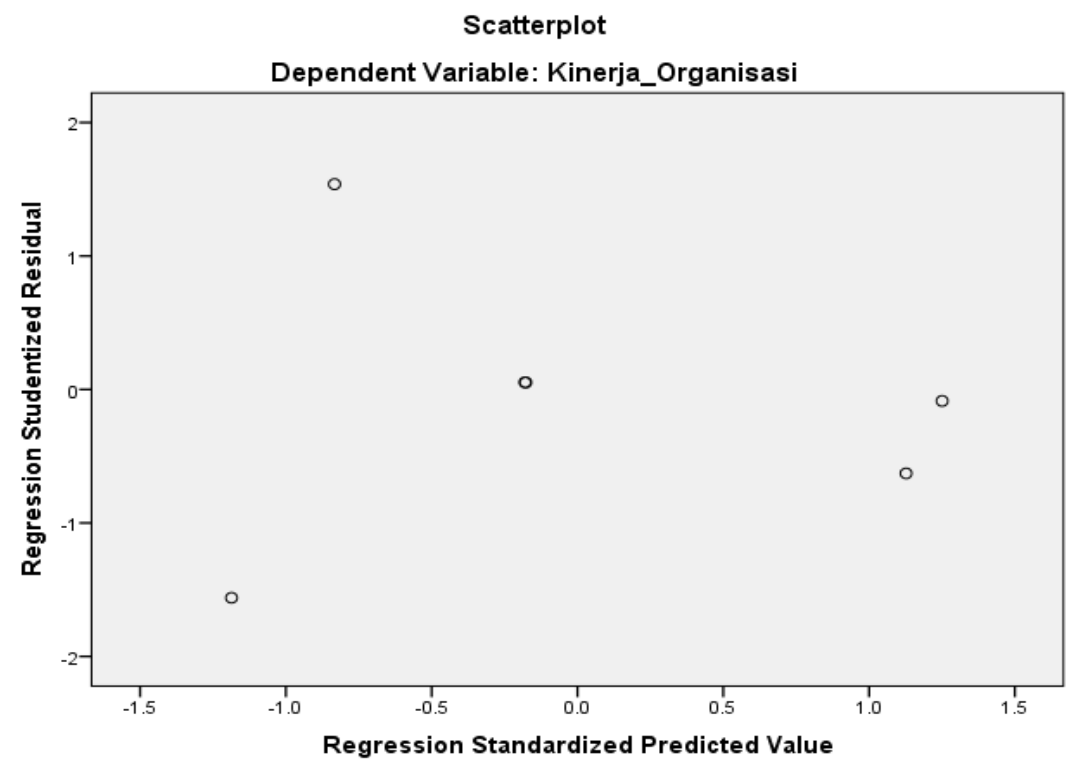

Gambar 4.10. Scatter Plot Uji Heteroskedastisitas

Sumber: Data yang diolah Peneliti 2017 


\section{JURNAL AKUNTANSI, Vol. 7, No. 2, November (2018)}

Dengan demikian, model regresi yang dibuat dalam penelitian ini tidak terbebas dari unsur heteroskedastisitas.

\section{Uji Regresi Linear Berganda}

Uji regresi linear berganda pada penelitian ini digunakan untuk mengetahui seberapa besar pengaruh antara variabel Cash Ratio (X1) dan Current Ratio (X2) terhadap variabel Kinerja Organisasi (Y). Hasil uji regresi linear berganda dapat dilihat pada tabel dibawah ini

\section{Tabel 4.11}

Uji Regresi Linear Berganda Coefficients $^{\mathbf{a}}$

\begin{tabular}{|c|c|c|c|c|c|c|}
\hline \multirow{2}{*}{\multicolumn{2}{|c|}{ Model }} & \multicolumn{2}{|c|}{ Unstandardized Coefficients } & $\begin{array}{l}\text { Standardized } \\
\text { Coefficients }\end{array}$ & \multirow[b]{2}{*}{$\mathrm{t}$} & \multirow[b]{2}{*}{ Sig. } \\
\hline & & $\mathrm{B}$ & Std. Error & Beta & & \\
\hline \multirow[t]{3}{*}{1} & (Constant) & 62.537 & 31.485 & & 11.986 & .001 \\
\hline & Cash_Ratio & .314 & .467 & .774 & 8.245 & .002 \\
\hline & Current_Ratio & .220 & .384 & .985 & 6.312 & .005 \\
\hline
\end{tabular}

Sumber: data yang diolah Peneliti 2017

Berdasarkan data diatas diperoleh nilai konstanta dan koefisien regresi yang dapat disubtitusikan kedalam persamaan regresi dibawah ini.

$$
\begin{gathered}
Y=a+b_{1} X_{1}+b_{2} X_{2}+e \\
Y=62.537+0.314 X 1+0.220 X 2+e
\end{gathered}
$$

Persamaan tersebut memiliki makna:

1. Nilai konstanta (a) $=62.537$ artinya; ketika variabel Cash Ratio dan Current Ratio bernilai konstan (nol) maka variabel Kinerja Organisasi telah memiliki nilai sebesar 62.537 satuan.

2. Nilai koefisien regresi (b1) $=0.314$ artinya; ketika terjadi peningkatan nilai pada variabel Cash Ratio sebesar satu satuan dengan asumsi variabel Current Ratio tetap, maka variabel Kinerja Organisasi juga mengalami peningkatan sebesar 0.314 satuan.

3. Nilai koefisien regresi $(\mathrm{b} 2)=0.220$ artinya; ketika terjadi peningkatan nilai pada variabel Current Ratio sebesar satu satuan dengan asumsi variabel Cash Ratio tetap, maka variabel Kinerja Organisasi juga mengalami peningkatan sebesar 0.220 satuan.

\section{Uji Hipotesis}

Hasil uji t pada output regresi linear berganda dapat dilihat pada tabel berikut.

Tabel 4.12

\section{Hasil Uji t (Parsial)}

\begin{tabular}{|l|c|r|r|}
\hline \multicolumn{2}{|c|}{ Model } & \multicolumn{1}{|c|}{$\mathrm{t}$} & \multicolumn{1}{l|}{ Sig. } \\
\hline \multirow{2}{*}{1} & (Constant) & 11.986 & .001 \\
\cline { 2 - 4 } & Cash Ratio & 8.245 & .002 \\
\cline { 2 - 4 } & Current Ratio & 6.312 & .005 \\
\hline
\end{tabular}

Sumber: data yang diolah Peneliti 2017

Dari data di atas dapat terlihat bahwa pada interaksi antara variabel Cash Ratio (X1) terhadap Kinerja Organisasi $(Y)$ diperoleh nilai t hitung $=8.245$ dengan Sig. yaitu 0.002. Pada interaksi antara variabel Current Ratio (X2) terhadap Kinerja Organisasi (Y) diperoleh nilai t hitung $=6.312$ dengan Sig. yaitu 0.005. Jika dilihat dari nilai probabilitas 


\section{JURNAL AKUNTANSI, Vol. 7, No. 2, November (2018)}

signifikansinya dapat dikatakan bahwa interaksi antara Cash Ratio dengan Kinerja Organisasi memiliki nilai Sig. $<0,05$ yang artinya Cash Ratio berpengaruh signifikan terhadap Kinerja Organisasi. Kemudian nilai signifikansi dari interaksi antara Current Ratio dengan Kinerja Organisasi memiliki nilai Sig. $<0,05$ yang artinya Current Ratio berpengaruh signifikan terhadap Kinerja Organisasi.

\section{Uji Simultan (Uji F)}

Berdasarkan hasil uji $\mathrm{F}$ pada tabel diatas diperoleh nilai $\mathrm{F}$ hitung $=29.110$ dengan sig. sebesar 0.009. Nilai signifikansi yang diperoleh menunjukan Sig. < 0,05 yang artinya bahwa variabel Cash Ratio (X1) dan Current Ratio (X2) secara simultan (bersama-sama) berpengaruh signifikan terhadap variabel total pendapatan (Y).

\section{Uji Koefisien Determinasi}

Uji koefisien determinasi digunakan untuk mengetahui kontribusi dari variabel bebas $(\mathrm{X} 1$ dan $\mathrm{X} 2)$ terhadap variabel terikatnya $(\mathrm{Y})$ yang dapat dilihat dari nilai $R$ square pada tabel dibawah ini.

Tabel 4.15

Hasil Uji Koefisien Determinasi Model Summary ${ }^{\mathrm{b}}$

\begin{tabular}{|c|c|r|r|r|r|r|r|}
\hline & & & & & \multicolumn{3}{|c|}{ Change Statistics } \\
\cline { 5 - 8 } Model & $\mathrm{R}$ & R Square & $\begin{array}{c}\text { Adjusted R } \\
\text { Square }\end{array}$ & $\begin{array}{c}\text { Std. Error of } \\
\text { the Estimate }\end{array}$ & $\begin{array}{c}\text { R Square } \\
\text { Change }\end{array}$ & F Change & df1 \\
\hline 1 & $.662^{\mathrm{a}}$ & .669 & .552 & 6.22847 & .069 & 29.110 & 2 \\
\hline
\end{tabular}

Sumber: data yang diolah Peneliti 2017

Dari tabel di atas terlihat bahwa nilai $R$ square $=0.669$. Dengan demikian dapat diketahui besarnya nilai $\mathrm{KD}=0.669 \times 100 \%$ yaitu $66.9 \%$. Nilai tersebut menunjukkan bahwa $66.9 \%$ variansi dari variabel Kinerja Organisasi dapat dijelaskan oleh variansi variabel Cash Ratio dan Current Ratio, sedangkan sisanya dapat dijelaskan oleh variabel lain diluar model (error) yaitu sebesar $33.1 \%$.

\section{PEMBAHASAN}

\section{Pengaruh Cash Ratio terhadap Kinerja Organisasi}

Berdasarkan hasil analisis dengan uji t diperoleh bahwa pada interaksi antara Cash Ratio (X1) terhadap Kinerja Organisasi (Y) diperoleh nilai t hitung = 8.245 dengan Sig. yaitu 0.002. Jika dilihat dari nilai probabilitas signifikansinya dapat dikatakan bahwa semua interaksi antara Cash Ratio dengan Kinerja Organisasi memiliki nilai Sig. $<0,05$ yang artinya Cash Ratio berpengaruh signifikan terhadap Kinerja Organisasi. Selanjutnya dengan melihat nilai tabel statistik $\mathrm{t}$ sesuai alpha (taraf signifikansi) yang digunakan yaitu $0,05 \mathrm{dan} \mathrm{df}=3$, diperoleh $\mathrm{t}$ tabel yaitu 3,1824. Dengan demikian terlihat bahwa t hitung $>\mathrm{t}$ tabel $(8.245>3,1824)$, hal ini mempertegas bahwa Cash Ratio berpengaruh signifikan terhadap Kinerja Organisasi perusahaan. Sementara itu nilai koefisien regresi bernilai positif (0.314) artinya; terdapat hubungan yang searah antara Cash Ratio terhadap Kinerja Organisasi perusahaan. Dengan semakin meningkatnya Cash Ratio maka akan semakin meningkat juga Kinerja Organisasi yang diperoleh perusahaan secara signifikan. 


\section{Pengaruh Current Ratio terhadap Kinerja Organisasi}

Berdasarkan hasil analisis dengan uji t diperoleh bahwa pada interaksi antara Current Ratio (X1) terhadap Kinerja Organisasi (Y) diperoleh nilai t hitung $=6.312$ dengan Sig. yaitu 0.005. Jika dilihat dari nilai probabilitas signifikansinya dapat dikatakan bahwa semua interaksi antara Cash Ratio dengan Kinerja Organisasi memiliki nilai Sig. < 0,05 yang artinya Current Ratio berpengaruh signifikan terhadap Kinerja Organisasi. Selanjutnya dengan melihat nilai tabel statistik t sesuai alpha (taraf signifikansi) yang digunakan yaitu $0,05 \mathrm{dan} \mathrm{df}=3$, diperoleh $\mathrm{t}$ tabel yaitu 3,1824. Dengan demikian terlihat bahwa $\mathrm{t}$ hitung $<\mathrm{t}$ tabel $(6.312<3,1824)$, hal ini mempertegas bahwa Current Ratio tidak berpengaruh signifikan terhadap Kinerja Organisasi perusahaan. Sementara itu nilai koefisien regresi bernilai positif $(0.220)$ artinya; terdapat hubungan yang searah antara Current Ratio terhadap Kinerja Organisasi perusahaan. Dengan semakin meningkatnya Current Ratio maka akan semakin meningkat juga Kinerja Organisasi yang diperoleh perusahaan namun tidak secara signifikan.

\section{Pengaruh Cash Ratio dan Current Ratio terhadap Kinerja Organisasi}

Berdasarkan hasil uji $\mathrm{F}$ diperoleh nilai $\mathrm{F}$ hitung $=29.110$ dengan sig. sebesar 0.009. Jika dilihat dari nilai signifikansi, maka diperoleh Sig. $<0,05(0.009<0,05)$ yang artinya variabel Cash Ratio (X1) dan Current Ratio (X2) secara simultan (bersama-sama) berpengaruh signifikan terhadap variabel total pendapatan $(\mathrm{Y})$. sementara itu diperoleh juga nilai $R$ square $=$ $0.669(66.9 \%)$. Nilai tersebut menunjukkan bahwa $66.9 \%$ variansi dari variabel Kinerja Organisasi dapat dijelaskan oleh variansi variabel Cash Ratio dan Current Ratio, sedangkan sisanya dapat dijelaskan oleh variabel lain diluar model. Dengan demikian dapat disimpulkan bahwa Cash Ratio dan Current Ratio secara simultan berpengaruh terhadap Kinerja Organisasi Study Kasus (Pada PT JIEP Pulogadung) Jakarta dengan kontribusi 66.9\%.

\section{PENUTUP}

Berdasarkan hasil penelitian menunjukkan bahwa Cash Ratio secara parsial berpengaruh positif dan signifikan terhadap Kinerja Organisasi Study. Pada Current Ratio secara parsial tidak berpengaruh signifikan terhadap profit Study dan Anggaran pendapatan dan anggaran biaya secara simultan berpengaruh signifikan terhadap profit Study Kasus (Pada PT JIEP Pulogadung) Jakarta tahun 2010-2015.

Berdasarkan hasil penelitian dan pembahasan, perusahaan sebaiknya menjaga tingkat rasio likuiditas yang optimal untuk menghindari adanya tingkat likuiditas yang terlalu tinggi, karena tingkat likuiditas yang terlalu tinggi menandakan adanya aktiva lancar yang berlebih diperusahaan yang seharusnya bisa dipergunakan secara efisien untuk meningkatkan laba. Begitu pula sebaliknya bila terlalu rendah maka kurang efektif aktiva perusahaan untuk menghasilkan laba perusahaan. Perusahaan sebaiknya meningkatkan margin laba perusahaan dan lebih efisien dan efektif dalam mengawasi biaya operasional, sehingga bisa menekan biaya operasional yang terus meningkat dan laba yang diperoleh semakin tinggi.

Penelitian ini hanya mengukur kinerja keuangan perusahaan 4 alat analisis rasio keuangan saja, sebaiknya penelitian selanjutnya menganalisis rasio keuangan lainya agar memperoleh hasil kinerja keuangan yang lebih baik dan tidak hanya berfokus pada perusahaan saja yang sejenis.

\section{REFERENSI}

Helfert, Erich A. 1996. Teknik Analisis Keuangan, Terjemahaan Edisi Kedelapan. Jakarta Erlangga.

Mahmud M. Hanafi. 2005. Analisis Laporan Keuangan, Edisi Kedua. Yogyakarta: UPP AMP YKPN

Haryono, Yusuf. 2005. Dasar-dasar Akuntansi. Yogyakarta: STIE YKPN

Harahap, Sofyan Syafri. 2004. Analisis Kritis Laporan Keuangan, Edisi 1. PT Raja Grafindo Persada. Jakarta 


\section{JURNAL AKUNTANSI, Vol. 7, No. 2, November (2018)}

. 2006. Analisis Kritis Atas Laporan Keuangan, Edisi Kelima. Jakarta: PT Raja Grafindo Persada.

2007. Analisis Kritisatas Laporan Keuangan. PT. Raja Grafindo Persada. Jakarta.

Mardiasmo. 2004. Akuntansi Sektor Publik. Yogyakarta : Ansi Yogyakarta.

Munawir. 2002. Analisis Laporan Keuangan. Yogyakarta: Liberty.

Munawir. 2004. Analisis Laporan Keuangan. Yogyakarta: Liberty.

Prastow, Dwi, dan Rifka, Juliaty. 2002. Analisis Laporan Keuangan konsep dan Aplkasi. Edisi Revisi. Yogyakarta: UPP AMP YKPN.

Suwarjono. 2002. Akuntansi Pengantar : Proses Penciptaan Data Pendekatan Sistem. Yogyakarta : BPFE.

Sartono, Agus. 2006. Manajemen Keuangan. Yogyakarta: BPFE UGM.

Keputusan Menteri Badan Usaha Milik Negara Nomor: Kep/117/M-MBU/2002, Tanggal 1

Agustus 2002 Tentang Good Cprporate Governance. Jakarta

Kasmir, 2008. Analisis Laporan Keuangan. Jakarta: Persada Raja Grafindo Persada.

Undang-undang Republik Indonesia Nomor 1 Tahun 2004 Tentang Perbendaharaan Negara. Jakarta.

Undang-undang Republik Indonesia. Nomor 19 Tahun 2003, Tentang Badan Usaha Milik Negara. Jakarta

Prayitno, Ryanto Hadi. 2010. Peranan Analisa Laporan Keuangan dalam Mengukur Kinerja Keuangan Perusahaan: Studi Kasus Pada PT. X. Jurnal Manajemen UNHUR Bandung Volume 2 No.1. Universitas Nurtanio. Bandung. Hal. 9.

Standar Akuntansi Keuangan, Per 1 September 2007. IAI. Salemba Empat

Pusat Penelitian dan Pengembangan Pengawasan BPKP (2012), Kajian : Instrumen Pengukuran Akuntabilitas Pengelolaan Keuangan Negara.

Baridwan, Zaki. 2004. Intermediate Accounting, Edisi Kedelapan. Cetakan Pertama. BPFE Universitas Gajah Mada. Yogyakarta

Fahmi, Irham. 2011. Analisis Kinerja Keuangan. Bandung: Alfabeta

Fahmi, Irham. 2012. Analisis Kinerja Keuangan. Alfabeta. Bandung.

Fahmi, Irham. 2012. Analisis Laporan Keuangan. Cetakan ke-2. Bandung: Alfabeta.

Fidhayatin, Septi Kurnia. 2012. Analisis Nilai Perusahaan, Kinerja Perusahaan Dan Kesempatan Bertumbuh Perusahaan Terhadap Return Saham Pada Perusahaan Manufaktur Yang Listing di BEI. Jurnal Akuntansi. Vol.2, No.2:205, Juli 2012.

Latifa Agustin. 2010. Analisis Faktor-faktor yang mempengaruhi Eefektifitas Audit Internal Dalam Mewujudkan Good Corpoorate Governance. Skripsi. Universitas Islam Syarif Hidatatullah. Jakarta

Hery. 2012. Analisis Laporan Keuangan. Jakarta: PT. Bumi Aksara.

Ikatan Akuntansi Indonesia. 1998. Standar Akuntansi Indonesia PSAK No 31. Buku 2. Salemba Empat. Jakarta

Ikatan Akuntansi Indonesia. 2009. Standar Akuntansi Keuangan: PSAK No. 1 - Penyajian Laporan Keuangan. Salemba Empat. Jakarta. Hal. 3.

Jumingan. 2005. Analisis Laporan Keuangan. Jakarta: PT. Bumi Aksara.

Kasmir. 2008. AnalisisLaporanKeuangan. Jakarta: PT. Raja GrafindoPersada.

Kasmir. 2012. AnalisisLaporanKeuangan. PT. RajagrafindoPersada. Jakarta.

Kasmir. 2014. Manajemen Perbankan. Edisi Revisi. Cetakan ke-12. Jakarta: PT. Raja Grafindo Persada.

Munawir,S, 2002. Analisis Laporan Keuangan, Edisi Keempat, Cetakan Kesebelas, Penerbit Liberty, Yogyakarta.

Orniati, Yuli. 2009. Laporan Keuangan sebagai Alat untuk Menilai Kinerja Keuangan. Jurnal Ekonomi: Universitas Gajayana Malang.

Prastowo, D dan R. Yuliaty.2005. Analisis Laporan Keuangan (konsep) dan Aplikasi. Edisi Kedua. CetakanPertama. UDP-ANP Y 


\section{JURNAL AKUNTANSI, Vol. 7, No. 2, November (2018)}

Abdullah, M. Faisal. 2003. Manajemen Perbankan (Teknik Analisis Kinerja Keuangan Bank). Malang: Umpress.

Beda, Petrus. 2005. Kinerja Keuangan PT. Media Pedoman Rakyat (Studi Kasus pada Harian Pedoman Rakyat Periode Tahun 1999-2003). Makassar: Sekolah Tinggi Ilmu Ekonomi Patria Artha.

Darminto, Dwi Prastowo., Suryo, Aji. 2005. Analisis Laporan Keuangan Hotel. Yogyakarta: Andi.

Darsono dan Ashari. 2005. Pedoman Praktis Memahami Laporan Keuangan. Yogyakarta: Andi

Ikatan Akuntan Indonesia.2009. Standar Akuntansi Keuangan per 1 Juli 2009.Jakarta : Salemba Empat.

Iramani., Febrian, Erie. 2005. Financial Value Added: Suatu Paradigma dalam Pengukuran Kinerja dan Nilai Tambah Perusahaan. Jurnal Akuntansi dan Keuangan Vol.7 No. 1 Mei 2005.

Kristiawan, Pradana Yudha. 2007. Analisis Pengaruh EVA, MVA, dan ROI terhadap Harga Saham, Skripsi. Skripsi tidak diterbitkan Malang: Unibraw.

Kusumadiyanto, Andra. 2006. Analisis Laporan Keuangan untuk Menilai Kinerja Perusahaan pada Kelompok Industri Rokok, (Studi Survei pada Kelompok industry Rokok). Bandung: Fakultas Ekonomi Universitas Widyatama.

Nazir, Mohammad. 2003. Pengertian Metode Penelitian Deskriptif Analitis, (online)(http://www.google.co.id/url?sa=t\&rct=j\&q=\&esrc=s\&source=web\&cd=6\&cad $=$ rja \&ved=0CDYQFjAF\&url=http\%3A\%2F\%2Flontar.ui.ac.id\%2Ffile\%3Ffile\%3Ddigi tal\%2F129265-T\%252026803-Evaluasi\%2520implementasi.

Wati, L.N. 2017. Metodologi Penelitian Terapan Bisnis: Aplikasi SPSS, EVIEWS, SmartPLS, dan AMOS. Bandung: Mujahid Press. 